\title{
Facultative cleaning behaviour of juvenile Diplodus sargus (Sparidae) and its ecological role in marine temperate waters
}

\author{
José Neto ${ }^{1}$, Diana Vieira ${ }^{1}$, David Abecasis ${ }^{2}$, Joana Marques ${ }^{3}$, Leonel Gordo ${ }^{3}$, \\ Joana I. Robalo ${ }^{1}$, Regina Bispo ${ }^{4}$, Marta Araújo ${ }^{1}$, Frederico Almada ${ }^{1, *}$ \\ ${ }^{1}$ MARE - Marine and Environmental Sciences Centre, ISPA Instituto Universitário, Rua Jardim do Tabaco 34, \\ 1149-041 Lisboa, Portugal \\ ${ }^{2}$ Centre of Marine Sciences (CCMAR), University of the Algarve, Campus de Gambelas, 8005-139 Faro, Portugal \\ ${ }^{3}$ MARE - Marine and Environmental Sciences Centre, Faculdade de Ciências da Universidade de Lisboa, \\ 1749-016 Lisboa, Portugal \\ ${ }^{4}$ Departamento de Matemática e Centro de Matemática e Aplicações, Faculdade de Ciências e Tecnologia, \\ Universidade Nova de Lisboa, 2829-516 Caparica, FCT, UNL, Lisboa, Portugal
}

\begin{abstract}
The diversity and abundance of cleaner species have been frequently associated with ectoparasite load and ecological wealth of tropical fish communities. Cleaning behaviour in temperate regions has received less attention, with few labrid species being described as cleaners. The context and frequency of cleaning behaviour by juvenile white seabream Diplodus sargus are described. Surface observations from pontoons in yachting marinas were carried out based on a method used in a recent first report of cleaning behaviour by this northeastern Atlantic and Mediterranean sparid. A total of $51 \mathrm{~h}$ of observations revealed that these juveniles $(<10 \mathrm{~cm}$ total length [TL]) display similar or higher cleaning rates (13.1 cleaning events per hour) compared to other temperate cleaners. The high cleaning rates, high abundance of young D. sargus on rocky shores along their distribution area and preferential targeting of adults by coastal fisheries highlight the ecological importance of D. sargus. The most common client species include grey mullets (Mugilidae), which represent $93.5 \%$ of total cleaning events registered. Regarding TL, clients were 4.6 to 6.6 times larger than cleaners. Environmental factors such as water temperature $\left(14.0-24.0^{\circ} \mathrm{C}\right)$, wave exposure $(6.0-17.0 \mathrm{~s})$ and wind speed $\left(2.0-8.0 \mathrm{~m} \mathrm{~s}^{-1}\right)$ influence white seabream cleaning rates. Thus, a combination of factors may affect the health of temperate client fish communities. On a different perspective, these results also highlight the potential of juvenile D. sargus in integrated multitrophic aquaculture. In conclusion, white seabream cleaning behaviour plays an important role in temperate fish communities and its relevance in different habitats should be further assessed.
\end{abstract}

KEY WORDS: Cleaner fish · Temperate communities $\cdot$ White seabream $\cdot$ Ectoparasites $\cdot$ Symbiosis Resale or republication not permitted without written consent of the publisher

\section{INTRODUCTION}

Cleaning symbiosis is an association in which an organism defined as 'cleaner' removes parasites, dead tissue or unwanted food particles from the epidermis of a cooperating 'client' (Galeote \& Otero
1998). This behaviour has been described in a variety of terrestrial vertebrates, but it is especially common within marine ecosystems (Limbaugh 1961, Grutter 1999), with over 200 fish species already described as cleaners (Van Tassell et al. 1994, Arnal et al. 2006, Vaughan et al. 2017). Furthermore, Rosa 
et al. (2014) highlighted the ecological relevance of this behaviour for coastal communities and the possible threats it may face under a climate change context.

According to their behaviour, fish are classified as obligatory or facultative cleaners. The first group depends mostly on the food obtained from these interactions throughout their entire lifespan, while fishes from the second group exhibit this behaviour during a specific phase of their life-cycle and rely on other food sources (Arnal \& Côté 2000). Several studies indicate that cleaners choose their clients based upon their size and parasite loads (Grutter 1995, 1999, Arnal et al. 2000). Frequently cleaners defend small territories and tend to be sedentary, while many clients have a roaming lifestyle, risking being preyed upon during visits to these cleaning stations (Cheney \& Côté 2001, Oates et al. 2012).

A substantial number of factors intrinsic to each community influence the frequency of cleaning interactions, which may vary greatly amongst species (Floeter et al. 2007). Besides the relative importance of cleaning interactions and general difference in cleaning rates, obligatory cleaners seem to share some morphological characteristics. Physical traits such as small body size and contrasting striped patterns are common among obligatory cleaners, helping clients to recognize cleaners through common visual cues (Stummer et al. 2004).

Despite the number of species currently described as cleaners, the ecological relevance of cleaning interactions has been frequently debated (Cheney \& Côté 2005). While cleaner benefits remain obvious, difficulties assessing client gain during these interactions have been pointed out (Cheney \& Côté 2005). Episodes of cheating during cleaning activity have been described, with 'cleaners' biting healthy tissue from their clients, resulting in mucus loss and tissue injuries (Bshary \& Schäffer 2002, Grutter \& Bshary 2003). However, clients seem to actively choose the cleaners they interact with in order to avoid these occurrences and react adversely when cheating occurs (Bshary \& Schäffer 2002, Bshary \& Grutter 2005, Pinto et al. 2011).

In any case, cleaning interactions have an impact on the ecological relationships between clients and cleaners. Field experiments showed that completely removing cleaners from specific reefs affects the community with several fish opting to roam into other areas (Limbaugh 1961, Bshary 2003), highlighting the ecological importance of cleaners as key organisms within their respective communities (but see Grutter 1996a).
Cleaning interactions have been frequently studied in tropical fishes (Quimbayo et al. 2017, Sampaio et al. 2017, Vasco-Rodrigues et al. 2017) including the Indo-Pacific bluestreak cleaner wrasse Labroides dimidiatus (Grutter 1997) and the Caribbean and western Atlantic genus Elacatinus, namely the Caribbean sharknose cleaning goby E. evelynae (Johnson \& Ruben 1988, Sazima et al. 2000, Whiteman \& Côté 2002, Bertoncini et al. 2009, Narvaez et al. 2015).

However, few studies have focused on species in temperate regions (Limbaugh 1961, Van Tassell et al. 1994, Galeote \& Otero 1998). Most cleaner species belong to the families Labridae and Gobiidae with a worldwide distribution (Arnal et al. 2006, Baliga \& Law 2016), but there is no trend supporting the assumption that this behaviour is more frequent in tropical than in temperate waters (Hobson 1968).

An increasing number of studies in temperate regions have led to the recognition of additional cleaner species (Zander \& Sötje 2002, Weitzmann \& Mercader 2012), such as the northeastern Atlantic Symphodus melops (Potts 1973) and Centrolabrus exoletus (Henriques \& Almada 1997) and the Mediterranean Centrolabrus (Symphodus) melanocercus (Baliga \& Law 2016) (see Almada et al. 2002, Hanel et al. 2002 for taxonomic clarifications). To a lesser extent, Coris julis, Thalassoma pavo (Labridae) (Van Tassell et al. 1994) and Lepadogaster candolii (Gobiesocidae) (Weitzmann \& Mercader 2012) have also been reported as cleaner species in the temperate northeastern Atlantic and Mediterranean. For this reason, many species are currently being used as cleaners in fish farms, which has been particularly evident in the salmon aquaculture industry (Robalo \& Mirimin 2018).

Sparids in general, and Diplodus sargus in particular, represent a striking example that illustrates the strong deficiency regarding field observations of this symbiotic behaviour in temperate regions. Several Diplodus species contribute greatly to fish assemblages in Atlanto-Mediterranean rocky habitats (Rosecchi 1987, Sala \& Ballesteros 1997, Dias et al. 2016). Sympatric species such as $D$. sargus, D. vulgaris and $D$. puntazzo have a diverse omnivorous diet while coexisting in the same ecosystem. Several studies have aimed to investigate the feeding habits of these species in order to understand, among other factors, potential food partitioning, prey preference and habitat use (Rosecchi 1987, Sala \& Ballesteros 1997, Figueiredo et al. 2005, Leitão et al. 2007). In these studies, the composition of the diet of $D$. sargus proved to be highly opportunistic. Notably, Rosecchi (1987) identified small ectoparasite copepods (Cali- 
gus pageti) commonly found on the epidermis of grey mullets (Mugilidae). Nevertheless, this fact was interpreted as occasional cleaning of conspecifics. Other authors confirmed the presence of ectoparasites in the stomach contents of $D$. sargus (Mariani 2001) and another highly similar species, common in the Mediterranean Sea, D. puntazzo (Moosleitner 1980, Van Tassell et al. 1994).

Behavioural reports of cleaning activity by congeneric sparid fish were only described later for the south American silver porgy $D$. argenteus (Krajewski 2007), and recently for D. sargus (Abecasis \& Abecasis 2015). Both studies represent first reports and neither of them aimed to quantify the cleaning behaviour in sparids in order to evaluate their ecological role in each community. Based on field observations, this work aims to describe the context and frequency of the cleaning behaviour of juvenile $D$. sargus. The ecological relevance of this facultative cleaner species is compared to the information currently available for other temperate cleaner species. and coastal lagoons. This was probably the reason why this conspicuous behaviour was only recently described by Abecasis \& Abecasis (2015), based on visual observations from floating piers in yachting marinas. The same methodology was adopted in this work.

Overall concordance between observers was achieved with video recordings and visual estimations of the total lengths (TLs) of cleaners and clients. Preliminary data collected during this calibration phase was discarded from the analysis. To minimize limitations to visual observations, data were collected in sheltered areas near rocks along the margins of the marinas.

\subsection{Cleaners and clients}

Cleaners were classified according to their size in 5 classes, with intervals of $2.5 \mathrm{~cm}$ up to $10 \mathrm{~cm}$, with the last class including fish with more than $10 \mathrm{~cm}$ TL.

\section{MATERIALS AND METHODS}

\subsection{Field surveys}

Field observations were performed in 3 marinas along the west coast of Portugal in Oeiras $\left(38^{\circ} 40^{\prime} 34^{\prime \prime} \mathrm{N}\right.$, $\left.9^{\circ} 19^{\prime} 05^{\prime \prime} \mathrm{W}\right)$, Tróia $\left(38^{\circ} 29^{\prime} 36^{\prime \prime} \mathrm{N}, 8^{\circ} 54^{\prime}\right.$ $\left.10^{\prime \prime} \mathrm{W}\right)$, and Póvoa de Varzim $\left(41^{\circ} 22^{\prime}\right.$ $08^{\prime \prime} \mathrm{N}, 8^{\circ} 45^{\prime} 49^{\prime \prime} \mathrm{W}$ ) from June 2014 to October 2015, and on the Spanish Mediterranean coast in Barcelona (41 ${ }^{\circ} 24^{\prime}$ $50^{\prime \prime} \mathrm{N}, 2^{\circ} 13^{\prime} 39^{\prime \prime} \mathrm{E}$ ) in June 2019. The number of observations for each location is shown in Table 1. In addition, non-quantitative cleaning behaviour reports were registered in other locations along the distribution area of this species, namely in the Azores, North Spain and Italy. All sampling sites are shown in Fig. 1.

Direct observations were made while standing on pontoons carefully avoiding disturbing the fish. Video recordings of some observations were also made. SCUBA divers and underwater cameras were ineffective, as both cleaners and clients flee in the presence of the observer, even in semi-confined areas such as marinas
Table 1. Distribution of observation hours, cleaning events, nips and duration of cleaning events for Diplodus sargus at each location

\begin{tabular}{|lcccc|}
\hline Location & $\begin{array}{c}\text { Observa- } \\
\text { tions (h) }\end{array}$ & $\begin{array}{c}\text { Cleaning } \\
\text { events }\end{array}$ & Nips & $\begin{array}{c}\text { Total duration of } \\
\text { cleaning events (s) }\end{array}$ \\
\hline Marina de Oeiras & 31 & 427 & 1105 & 3147 \\
Marina de Póvoa de Varzim & 9 & 101 & 304 & 838 \\
Marina de Tróia & 5 & 78 & 289 & 880 \\
Port Fòrum Barcelona & 5 & 44 & 129 & 382 \\
Total & 50 & 650 & 1827 & 5247 \\
\hline
\end{tabular}

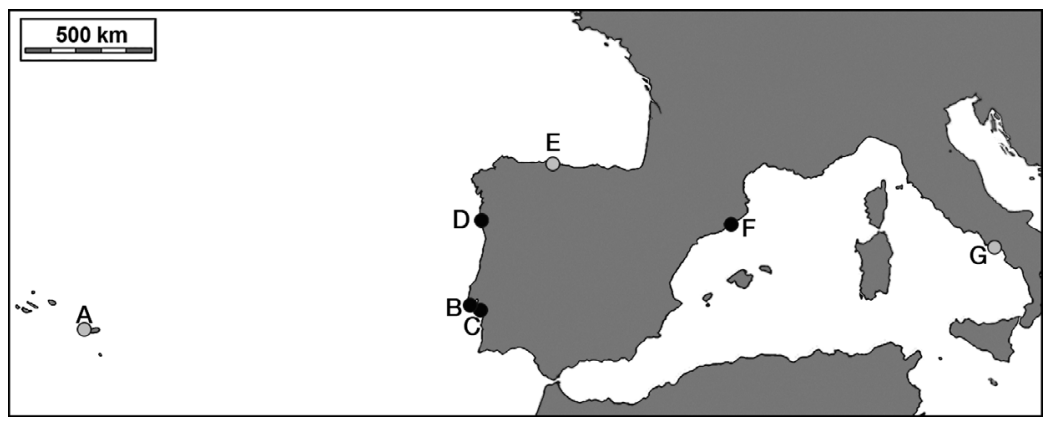

Fig. 1. Locations where cleaning behaviour by juvenile Diplodus sargus was observed. (-) Locations where the quantitative data used in this work was gathered; ( ) locations where cleaning behaviour by juvenile $D$. sargus was observed but no quantitative data was collected. (A) Termas da Ferraria; São Miguel (Azores); (B) Marina de Oeiras (continental Portugal); (C) Marina de Tróia (continental Portugal); (D) Marina de Póvoa de Varzim (continental Portugal); (E) Puerto Deportivo de Gijón (Spain); (F) Port Fòrum Barcelona (Spain); (G) Marina di Puolo (Italy) 
Clients, being conspicuously larger than cleaners, were also classified in 5 size classes, with intervals of $10 \mathrm{~cm}$ up to $40 \mathrm{~cm}$, with the last class including all fish with more than $40 \mathrm{~cm}$ TL.

To evaluate if cleaner fish target any particular section of their client's body, cleaning events were described according to the targeted area: (1) head, starting from the tip of the snout to the base of the pectoral fin; (2) flank, starting from the base of the pectoral fin to the base of the anal fin; and (3) tail, from the anal fin to the tip of the tail.

To evaluate the cleaning frequencies of juvenile $D$. sargus, 2 different methods were implemented: (1) group scans, in which fish could freely abandon or enter the observation area that consisted of a $2 \times 2 \mathrm{~m}$ square with presence of juvenile $D$. sargus chosen randomly within the shallow area of the yachting marina. A total of 50 observation periods, $1 \mathrm{~h}$ each, were performed to evaluate the frequency of this behaviour per area; (2) focal observations of individual fish were performed following 50 randomly chosen juvenile $D$. sargus that were followed for as long as they could be sighted during a total of $105 \mathrm{~min}$ $(2.10 \pm 1.76 \mathrm{~min})$. These observations were performed to evaluate individual frequency of this behaviour.

Cleaning events were registered starting with the first physical contact between cleaner and client and ending with the separation of the pair (sensu Johnson \& Ruben 1988). These events could involve 1 or several nips. For each cleaning event, total duration, number of nips and client reaction were recorded. Client reaction was considered 'positive' whenever the client remained motionless or slowly swimming, and 'negative' whenever the client reaction changed in response to contact, resulting in a jolt. A visual inspection was reported whenever a juvenile $D$. sargus swam directly into close range (less than half the client's body length) of a potential client and no contact was observed between them. Visual inspections that were not followed by a cleaning event were further described in order to evaluate which fish was responsible for the separation: the client swimming away from the cleaner or the cleaner swimming in another direction, losing interest in its potential 'client'. These interactions are shown in Fig. 2.

Client behaviour was also recorded. Cleaning requests commonly include head-up or head-down displays at an angle of 45 to $90^{\circ}$ accompanied by an interruption of the normal swimming pattern (sensu Galeote \& Otero 1998, Stummer et al. 2004). Ambiguous situations were discarded.

In order to evaluate whether there is a preference for a particular set of target species, local abundances of potential clients must be accounted for. A preference for specific clients could be explained by (1) a bias towards species with a particular set of characteristics; or (2) randomly targeting potential clients according to their abundances in the study area. To evaluate a possible bias of juvenile $D$. sargus, 10 visual censuses were conducted to estimate relative abundances of local ichthyofauna (Table 2).

Statistical analysis was performed with $\mathrm{R}$ version 3.6.0 (R Development Core Team 2019). The number of cleaning events observed in group scans along the Portuguese coast was analysed via Generalized Linear Models (GLM) with a Poisson distributional family. Environmental variables (listed in Table 3) were used as explanatory variables. Daily mean wave period, wave height and wind speed data were obtained using the Global Forecast System model available at www.windguru.cz. All other environmental variables were collected during field observations. The most parsimonious model was selected based on the Akaike Information Criterion and incident rate ratios (IRR) were obtained by exponentiating the Poisson regression coefficients. Model residuals were checked and no significant deviation from the assumed distribution was found.

Frequency of nips by cleaners with different TLs targeting distinct client body areas and positive and

Table 2. Distribution of the cleaning interactions between juvenile Diplodus sargus and each client species and relative client species abundances in the study area. Information regarding species with low relative abundance that were never observed to interact with $D$. sargus is not shown

\begin{tabular}{|lcccc|}
\hline Host & $\begin{array}{c}\text { Cleaning } \\
\text { events }\end{array}$ & $\begin{array}{c}\text { \% of total } \\
\text { cleaning events }\end{array}$ & $\begin{array}{c}\text { Cleaning } \\
\text { solicitations }\end{array}$ & $\begin{array}{c}\text { Relative } \\
\text { abundance }\end{array}$ \\
\hline Mugilidae & 608 & 93.54 & 5 & 0.34 \\
Sarpa salpa & 14 & 2.15 & 2 & 0.01 \\
Boops boops & 11 & 1.69 & 3 & 0.24 \\
Diplodus sargus & 10 & 1.54 & 2 & 0.16 \\
Seriola sp. & 3 & 0.46 & 0 & 0.00 \\
Dicentrarchus labrax & 2 & 0.31 & 0 & 0.00 \\
Symphodus melops & 1 & 0.15 & 0 & 0.00 \\
Oblada melanura & 1 & 0.15 & 0 & 0.01 \\
Atherina presbyter & 0 & 0.00 & 0 & 0.21 \\
Diplodus vulgaris & 0 & 0.00 & 0 & 0.02 \\
Total & 650 & & 12 & \\
\hline
\end{tabular}




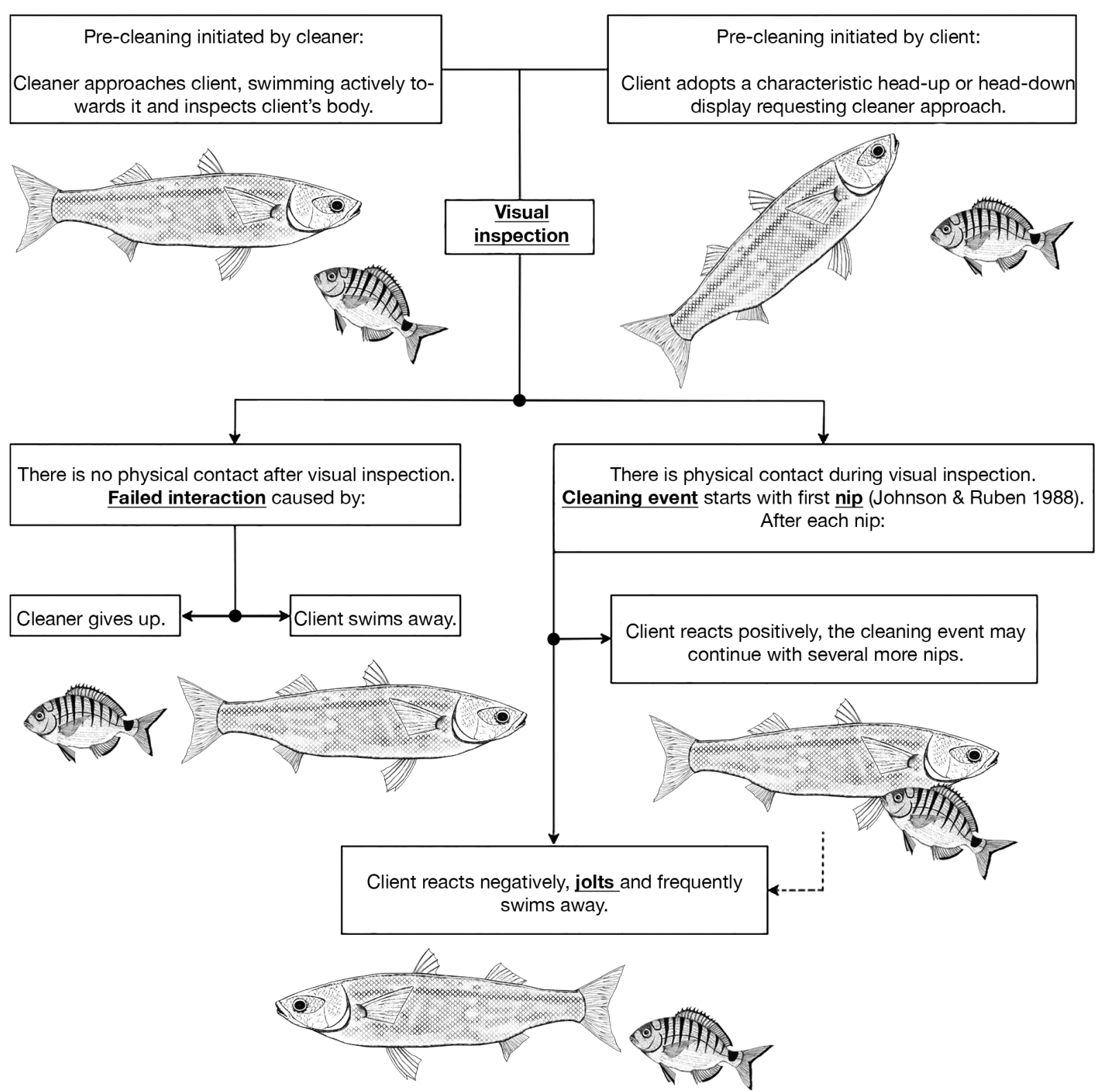

Fig. 2. Schematic representation of the interactions between Diplodus sargus (the cleaner) and its clients, represented here by a mugilid. Note: terms underlined and bold are not used uniformly in the literature

negative reaction to nips by clients of different sizes were analysed with ACTUS2 (Estabrook et al. 2002), using 1000 simulations under a 0.05 significance level.

\subsection{Ectoparasites in stomach contents}

Rosecchi (1987) and Mariani (2001) previously reported the presence of ectoparasites in the stomach contents of juvenile D. sargus. Four juvenile $D$. sargus were captured in 2015 (TL $7.4 \pm 1.4 \mathrm{~cm}$ ) within the study area to confirm a direct relationship between cleaning behaviour observations and the presence of ectoparasites in stomach contents. Fish were sacrificed with a lethal dose of anaesthetics (300 $\mathrm{mg} \mathrm{l}^{-1}$ MS222 tricaine methane sulphonate; Pharmaq) in strict accordance with the recommendations of the Animal Care and Use Committee of ISPA Instituto Universitário (ORBEA-ISPA). This study did not involve endangered or protected species and was not performed in a marine protected area, therefore no permission for capturing fish was needed. 
Table 3. Range of observations (minimum, mean and maximum) for quantitative environmental variables and number of observations for qualitative environmental variables

\begin{tabular}{|c|c|c|c|c|}
\hline \multicolumn{2}{|c|}{ Environmental variable } & Minimum & Mean & Maximum \\
\hline \multicolumn{2}{|c|}{ Water temperature $\left({ }^{\circ} \mathrm{C}\right)$} & 14.00 & 18.92 & 24.00 \\
\hline \multicolumn{2}{|c|}{ Visibility $(\mathrm{m})$} & 0.30 & 1.28 & 3.00 \\
\hline \multicolumn{2}{|c|}{ Daily mean wave height (m) } & 0.80 & 1.83 & 4.90 \\
\hline \multicolumn{2}{|c|}{ Daily mean wave period (s) } & 6.00 & 10.96 & 17.00 \\
\hline \multicolumn{2}{|c|}{ Daily mean wind speed $\left(\mathrm{m} \mathrm{s}^{-1}\right)$} & 2.00 & 4.73 & 8.00 \\
\hline \multicolumn{5}{|c|}{ Number of observations } \\
\hline Tidal period & High: 14 & Ebb: 14 & Low: 8 & Flood: 8 \\
\hline Moon phase & Full: 6 & Waning: 9 & New: 16 & Crescent: 14 \\
\hline Time of day & $\begin{array}{c}\text { Morning }(08: 00- \\
12: 00 \mathrm{~h}): 15\end{array}$ & $\begin{array}{c}\text { Noon } \\
15: 00\end{array}$ & $\begin{array}{l}01- \\
15\end{array}$ & $\begin{array}{l}\text { ernoon (15:01- } \\
19: 00 \text { h): } 15\end{array}$ \\
\hline
\end{tabular}

\section{RESULTS}

\subsection{Context and duration of cleaning events}

Considering both successful cleaning events and unsuccessful interactions, 1761 visual inspections were performed by Diplodus sargus during the $50 \mathrm{~h}$ of observation.

The 650 successful cleaning events (rate $13.0 \pm$ $7.7 \mathrm{~h}^{-1}$; mean $\pm \mathrm{SD}$ ) involved 1827 nips (rate $36.5 \pm$ $33.5 \mathrm{~h}^{-1}$ ) (see Video S1 in Supplement 1 at www.intres.com/articles/suppl/m629p165_supp/). Considering each individual cleaning event, the mean number of nips was $3.0 \pm 4.3$, and the average duration of interactions was $8.7 \pm 13.7 \mathrm{~s}$.

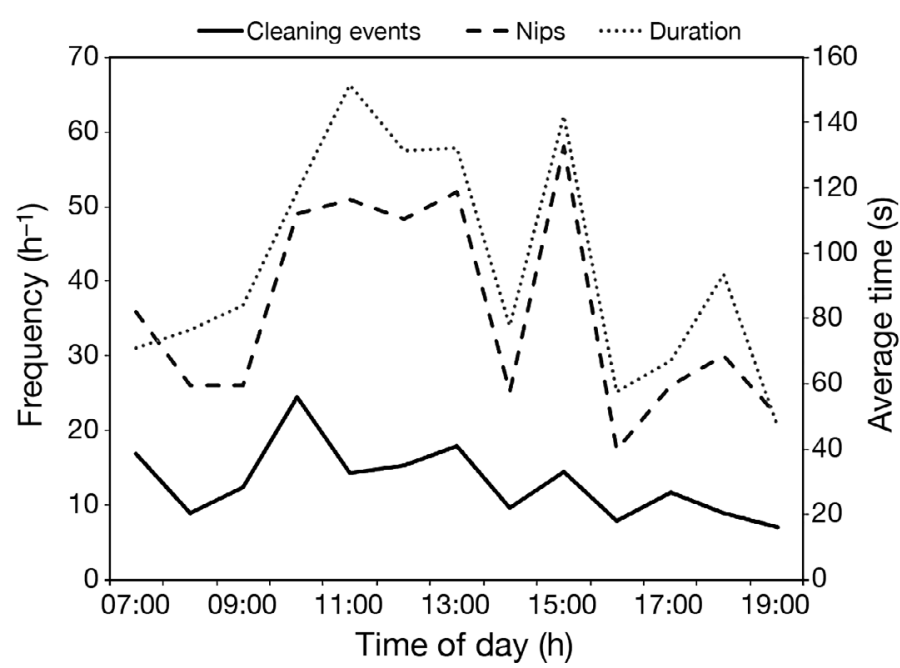

Fig. 3. Average number of cleaning events, average number of nips and average duration of cleaning events throughout the day for Diplodus sargus
Of the 1111 inspections not followed by cleaning events (number of failed inspections $\left.22.2 \pm 25.0 \mathrm{~h}^{-1}\right), 830$ $(74.7 \%)$ were due to avoidance by the potential client and $281(25.3 \%)$ were due to loss of interest by the cleaner D. sargus.

Cleaning events were observed in all months, except March 2015 when no juvenile $D$. sargus were observed at the sampling sites, from first daylight to sunset. The variation in the average number of cleaning events, average number of nips and average duration of cleaning events per hour throughout the day is depicted in Fig. 3.

The selected GLM model showed that environmental variables such as water temperature $(\mathrm{p}<0.001)$, wave period $(\mathrm{p}<$ $0.001)$ and wind speed $(\mathrm{p}<0.01)$ had a positive effect on the frequency of cleaning events observed in group scans (see Table S1 in Supplement 2 at www. int-res.com/articles/suppl/m629p165_supp2.pdf). A significant decrease in cleaning events was observed towards the end of the day (morning-noon $\mathrm{p}<0.01$ and morning-afternoon $\mathrm{p}<0.001$ ) and differences between moon phases $(p<0.05)$ were also found (Table S1).

During cleaning events, juvenile $D$. sargus did not target their client's body randomly. Although total observed nips directed to the client's head, flank or tail were similar (601 nips directed to the head, 579 nips directed to the flank and 647 nips directed to the tail), there were differences between cleaners of different sizes. Analysis of contingency tables using ACTUS2 (Estabrook et al. 2002) indicated that smaller D. sargus $(<2.5 \mathrm{~cm}$ TL) show no preference, whilst slightly larger ones $(2.5-5.0 \mathrm{~cm}$ TL) significantly avoided the head section of their clients. In contrast, larger juveniles (5.0-10.0 cm TL) preferentially targeted their client's head section $\left(\chi^{2}=55.5, \mathrm{df}=6, \mathrm{p}<\right.$ 0.001) (Table S2).

\subsection{Cleaners and clients}

D. sargus juveniles were observed cleaning fish from 8 different taxa and the number of cleaning events per client species is shown in Table 2. A large proportion of clients $(93.5 \%)$ were grey mullets, with the most common species being thicklip grey mullets Chelon labrosus and golden grey mullets Liza aurata. In general, mugilids are one of the largest and most 
abundant groups of fish within the study area. Although C. labrosus represent the majority of the individuals observed in the sampled sites, their morphological similarities with other mugilid species (Reay \& Cornell 1988) led us to identify all subjects as 'Mugilidae' and no further attempt was made to identify them to the species level.

Cleaning solicitations, with client immobilization and conspicuous body tilting (cleaning solicitation) followed by a successful cleaning event, were observed 12 times during the observation period for 4 different taxa: mugilids $(\mathrm{n}=5)$, Boops boops $(\mathrm{n}=3)$, Sarpa salpa $(\mathrm{n}=2)$ and adult $D$. sargus $(\mathrm{n}=2)$.

Clients reacted positively to physical contact by hovering motionless or soliciting cleaning on 1312 occasions $(71.8 \%)$ as a response to continuous nips, sometimes by multiple cleaners (Video S2). Clients reacted negatively, swimming away and/or jolting, 515 times $(28.2 \%)$ as a reaction to a cleaning attempt or nip (Video S3).

Considering only negative reactions, clients terminated 421 interactions $(81.7 \%)$ after contact and cleaners lost interest and moved away in the remaining 94 events.

Analysis of the client reactions showed significantly high numbers of negative reactions by individuals with $10.0-20.0 \mathrm{~cm}$ TL $\left(\chi^{2}=15.0, \mathrm{df}=3, \mathrm{p}<0.01\right)$ (Table S3), meaning that only smaller clients tended to react negatively to an interaction with a cleaner.

It is worth noting that there was a reduction in nip frequency (cleaning success) with increasing $D$. sargus size for all client size classes (Fig. 4). This is further emphasized by the fact that smaller $D$. sargus $(<5 \mathrm{~cm})$ cleaned clients of all size classes while larger $D$. sargus $(>10.0 \mathrm{~cm})$ cleaned only larger clients $(>30.0 \mathrm{~cm})$.

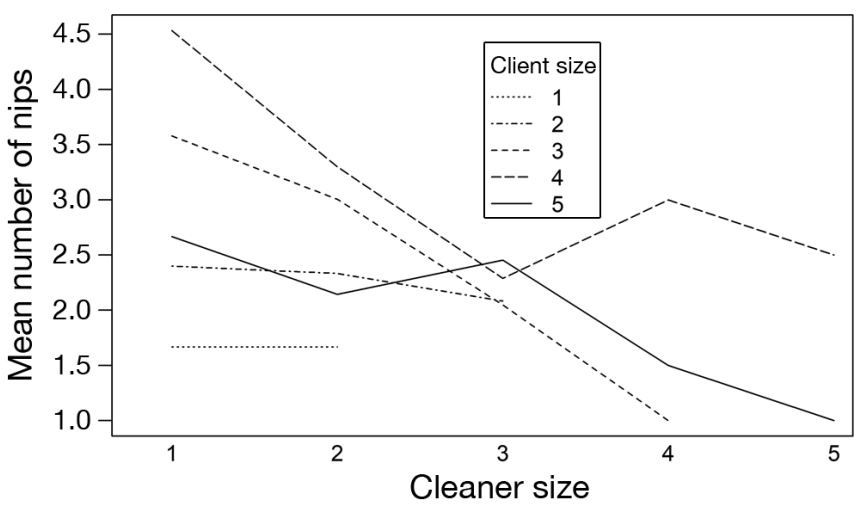

Fig. 4. Mean number of nips with increasing Diplodus sargus size for each client size class. Cleaner size $1:<2.5 \mathrm{~cm} ; 2$ : $2.5-5 \mathrm{~cm} ; 3: 5-7.5 \mathrm{~cm}_{i} 4: 7.5-10 \mathrm{~cm}_{i} 5:>10 \mathrm{~cm}$. Client size 1: $<10 \mathrm{~cm} ; 2: 10-20 \mathrm{~cm} ; 3: 20-30 \mathrm{~cm} ; 4: 30-40 \mathrm{~cm} ; 5:>40 \mathrm{~cm}$
The size relationship between client and cleaner seems to play an important role in these interactions. Considering successful interactions, clients were on average $4.6 \pm 2.3$ to $6.6 \pm 2.9$ times larger than their cleaners.

Mugilids represent the most abundant group within the study area with $B$. boops and Atherina presbyter (see Almada et al. 2017) being also very abundant. However, only a few cleaning events were directed towards these 2 species. In contrast, potential clients such as $S$. salpa showed the opposite pattern, with low abundances in all field surveys, although they were the species second most frequently cleaned by juvenile $D$. sargus. Overall, the abundance of client species is important but it does not explain preferential cleaning behaviour by this opportunistic species.

Interestingly, $D$. sargus juveniles were also observed cleaning 2 potential predators: Dicentrarchus labrax and Seriola sp., which are commonly observed preying on small fish within the study area.

Juvenile $D$. sargus were not the only sparids displaying cleaning behaviour in the study area. Although they have rarely been seen in the Atlantic, juvenile $D$. puntazzo have occasionally been observed cleaning other fish in the Mediterranean. However, other congeneric species, namely $D$. vulgaris, frequently observed in the study area, have never been observed cleaning other fish.

\subsection{Individual focal observations}

Fifty randomly chosen individuals were followed for $105 \mathrm{~min}(2.10 \pm 1.76 \mathrm{~min})$. Of these, $21(42 \%)$ were observed visually inspecting potential clients resulting in 44 failed interactions and 23 cleaning events, with a frequency of 13.1 successful cleaning events per hour. The average duration of each cleaning event was $8.2 \pm$ $16.6 \mathrm{~s}$, suggesting that $D$. sargus are involved in cleaning activities approximately $3 \%$ of their time.

\subsection{Ectoparasites in stomach contents}

Only 1 of 4 juvenile $D$. sargus captured had ectoparasites in its stomach contents. Three Lepeophtheirus sp. (Caligidae) (Fig. S1) were found in this fish. These results show that cleaning behaviour and the presence of parasites in the cleaner's stomach is simultaneously observed in the same location and during the same period of time, but do not exclude the possibility that these fish are also feeding on client fish mucus or tissue. 


\section{DISCUSSION}

\subsection{Cleaning behaviour by juvenile Diplodus sargus}

A high cleaning frequency (13.0 cleaning events per hour) by juvenile Diplodus sargus under $10 \mathrm{~cm}$ $\mathrm{TL}$, and the absence of cleaning activity by larger individuals, shows that cleaning behaviour is restricted to earlier life stages. According to the age/growth pattern reported by Gordoa \& Molí (1997) (further explored by Abecasis et al. 2008), cleaning activity is probably restricted to individuals up to $1 \mathrm{yr}$ old, meaning that seasonal interruptions of cleaning activity are probably short or absent, as a new cohort of post-larvae replaces the previous one with the onset of a new settlement phase. Field observations confirmed the occurrence of cleaning activity throughout the year, although a maximum frequency is expected during spring and summer accompanying the highest abundances of juvenile $D$. sargus. Considering daily activity patterns, the frequency of cleaning behaviour declined during the afternoon. These results are identical to the general feeding activity pattern described by Figueiredo et al. (2005) for this species. This pattern is also similar to other cleaner species such as the tropical Labroides dimidiatus (Grutter 1996b) and Bodianus rufus (Johnson \& Ruben 1988). Considering other variables, higher temperatures may result in higher activity rates, which may be less conspicuous in tropical species subjected to narrower temperature ranges. As described by Nunes et al. (2013), increasing wave exposure could limit access to additional food items, thus reducing reef fish activity outside the sheltered areas sampled in this study. An omnivorous opportunistic species such as D. sargus could increase cleaning frequency in sheltered areas as a response to compensate their feeding habits during these periods. The positive relationship between cleaning rates and wind speed described in this study could have the same effect. Additional studies are needed to better understand the increasing cleaning rates observed during new moon compared to waning moon quarters.

The presence of ectoparasites in the stomach contents of individuals inhabiting coastal lagoons was previously suggested by Rosecchi (1987) and Mariani (2001). However, the relative importance of D. sargus as a cleaner species was largely overlooked, probably due to limitations related to stomach content analysis (e.g. limited number of specimens under $10 \mathrm{~cm}$ TL, preservation and consequent identification of consumed ectoparasites). Recently, Abecasis \& Abecasis
(2015) reported cleaning behaviour by juvenile $D$. sargus stressing that its ecological relevance was yet to be evaluated.

Grey mullets (Mugilidae) were preferential client species and the most abundant taxa in the study area. Preferential cleaning behaviour and high cleaning rates could be mainly dependent on the abundance of specific clients (Galeote \& Otero 1998, Arnal et al. 2000). However, the inclusion of additional species revealed no direct relationship between species abundances and frequency of interactions, suggesting that more complex mechanisms are involved. Grutter (1995) and Arnal et al. (2000) reported that cleaning frequency was also related to factors such as client size. Other authors have highlighted the importance of client behaviour to determine both cleaning frequency and interaction outcome (Arnal \& Côté 2000, Zander \& Sötje 2002, Soares et al. 2008). Regarding client size, larger clients are usually more attractive to cleaners than smaller clients due to their higher parasite loads (Grutter 1995) and richer mucus (Arnal \& Morand 2001b). While size and local abundance of species are usually negatively correlated, the combined effect of high abundance and larger body size could help to explain the high frequency of interactions with a particular client (Floeter et al. 2007). Considering that grey mullets were the most abundant and among the largest fish species within the study area it was expected that they would also be preferential clients. On the other hand, Boops boops (Sparidae) and Atherina presbyter (Atherinidae) were highly abundant but commonly excluded as potential clients. This was probably due to the fact that their abundances were mainly due to the presence of schools of small juveniles with sizes that do not reach the threshold reported here. Sazima et al. (2000) reported previously that clients were on average 1.5 times larger than their cleaners, but the differences observed here are even higher, with $D$. sargus clients being usually 4.6 to 6.6 times larger, thus excluding smaller fish as potential clients.

Regarding client behaviour, clients may actively request cleaning interactions. Solicitation of cleaning was rare but this behaviour was observed in 4 different client species. In the large majority of cases, swimming slowly or resting near the surface triggered the cleaning behaviour of juvenile D. sargus. Interestingly, a single juvenile $D$. sargus interacted with an adult Sarpa salpa in a cleaning event that totalled $150 \mathrm{~s}$, involving 65 nips, to none of which the client reacted negatively. S. salpa is common in the northeastern Atlantic and Mediterranean and is known to interact with other cleaner species, often 
soliciting cleaning interactions (Henriques \& Almada 1997, Arnal \& Morand 2001b, Sabatino et al. 2007). This may suggest that $S$. salpa possesses the mechanisms required to recognize cleaners and interact with them. In addition, it is also interesting to note that $D$. sargus juveniles approached and cleaned potential piscivorous predators. Cleaners generally approach potential predators with caution and predators are very rarely cheated upon (Bshary 2002, Barbu et al. 2011). This suggests that the cleaning behaviour of juvenile $D$. sargus often requires client/ cleaner cooperation, highlighting their potential ecological role in northeastern Atlantic and Mediterranean fish communities. These 2 examples do not exclude the fact that a combination of cooperative and cheating interactions may coexist. In fact, the number of positive and negative reactions was different among grey mullets of different sizes. Smaller clients reacted negatively more often to inspections and to nips, while larger individuals often remained indifferent during cleaning interactions. This could be related to (1) larger clients suffering less damage, having higher tolerance and being less intimidated by cleaner approach and contact even if they cheat on some occasions (Pinto et al. 2011); and/or (2) client learning processes (Sabatino et al. 2007) starting with small unwilling clients, resulting in forced 'hit and run' interactions (Johnson \& Ruben 1988), with larger and less naïve clients being more likely to contact cleaners. In fact, a mutual learning process may underlie the interactions between $D$. sargus and their clients, with smaller naïve $D$. sargus choosing randomly or avoiding risks around the anterior part of the client's body, and larger and more experienced ones showing a preference for the head, gills and base of the pectoral fins. Considering that Alaş \& Öktener (2017) reported a higher persistence of parasites in the head region of their hosts, experienced cleaners may show preference for the anterior region of their client's body due to higher parasite loads in this area.

Visual observations do not show if cleaning interactions involve the removal of clients' ectoparasites or body mucus. As a first step to overcome this limitation, the frequency of cleaning behaviour observed in juveniles was compared with the ectoparasite load (Caligidae) in the stomach contents of D. sargus reported in the literature. Individual focal observations revealed that $24 \%$ of individuals $(\mathrm{n}=12)$ were engaged in cleaning events. Assuming that jolts may represent cheating occurrences with no removal of parasites from their hosts, only $18 \%$ of the individuals $(n=9)$ might have been involved in honest clean- ing activities. These results from behavioural observations are in agreement with the occurrence of ectoparasites in the stomach contents of 10 and $17.9 \%$ of the $D$. sargus examined by Rosecchi (1987) and Mariani (2001), respectively.

\subsection{Relative importance of $D$. sargus as a temperate facultative cleaner}

Cleaner fish contribute to the health of fish communities by controlling the ectoparasite load of numerous client species (Grutter \& Lester 2002). Studies focused on tropical ichthyofauna highlight the importance of this behaviour in the diet of obligatory cleaner species such as the Indo-Pacific bluestreak cleaner wrasse L. dimidiatus (Grutter 1996b) and the Caribbean sharknose cleaning goby Elacatinus evelynae (Johnson \& Ruben 1988, Whiteman \& Côté 2002, Côté \& Soares 2011).

Studies on temperate cleaner species are much less abundant, which is probably related to harsh sea conditions and the fact that temperate species are often facultative and not obligatory cleaners (Limbaugh 1961, Ayling \& Grace 1971, Potts 1973, Narvaez et al. 2015). In the temperate northeastern Atlantic and Mediterranean, cleaners are almost exclusively wrasses (Labridae) (Almada et al. 2002), with the main ones being the rock cook Centrolabrus exoletus in the Atlantic (Henriques \& Almada 1997) and $C$. melanocercus in the Mediterranean (Galeote \& Otero 1998, Arnal \& Morand 2001a, Sabatino et al. 2007) (see Treasurer 2018 for additional studies focusing on aquaculture applications).

Compared to tropical obligate cleaners, the cleaning rates of $D$. sargus were consistently low. However, these rates were unexpectedly high when compared with those from known sympatric temperate cleaners (Fig. 5). Although individual focal observations revealed a high number of interactions, they also showed that $D$. sargus spend less time cleaning (3\% for D. sargus compared to $13 \%$ for C. melanocercus; $118.6 \pm 8.4 \mathrm{~s}$ per $15 \mathrm{~min}$ period; Arnal \& Morand, 2001b), which points to the lack of specialization and lower dependency on cleaning activities of this opportunistic cleaner species.

Considering the overall diversity of client species, $D$. sargus targeted only 8 species while $C$. exoletus targeted 12 client species (Henriques \& Almada 1997) and C. melanocercus targeted 19 client species (Sabatino et al. 2007) (Table 4). Cleaning was higher for $D$. sargus ( $D$. sargus 13.0 cleaning events per hour, mean number of cleaning events per client spe- 


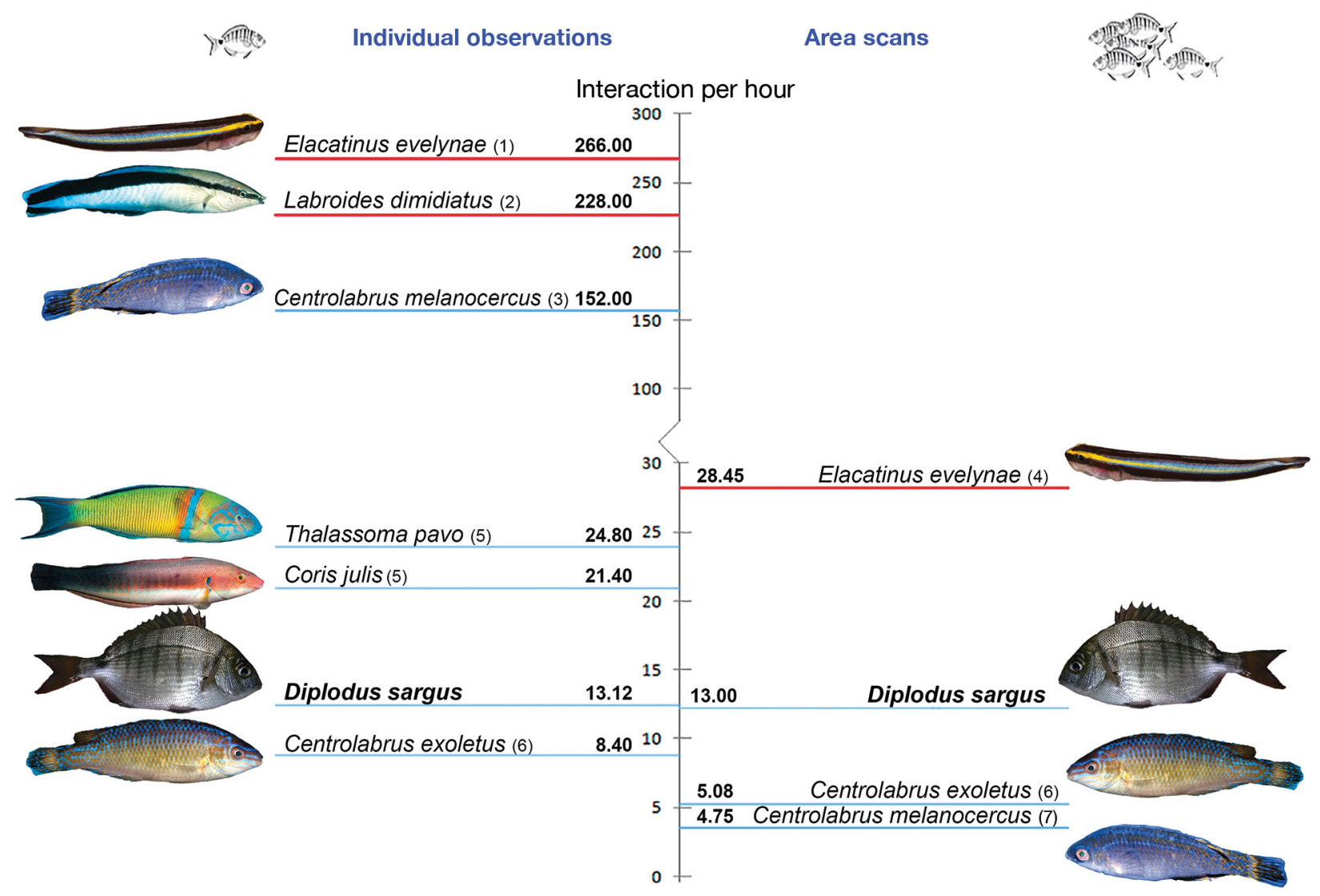

Fig. 5. Comparison of the cleaning frequencies of 5 different temperate cleaners (underlined in blue) and 2 tropical cleaners (underlined in red), as obtained through focal individual observations and local scans. Data for Diplodus sargus were obtained in this study; other data were obtained from (1) Whiteman \& Côté (2002), (2) Grutter (1996b), (3) Arnal \& Morand (2001a), (4) Johnson \& Ruben (1988), (5) Narvaez et al. (2015), (6) Henriques \& Almada (1997) and (7) Galeote \& Otero (1998)

cies $1.6 \pm 4.3 ;$ C. exoletus 5.1 cleaning events per hour, mean number of cleaning events per client species $0.4 \pm 0.8 ; C$. melanocercus 4.8 cleaning events per hour, mean number of cleaning events per client species $0.3 \pm 0.3$ ) but grey mullets accounted for $93.5 \%$ of all interactions, while the clients of C. exoletus and C. melanocercus were more evenly distributed (preferential target for C. exoletus was Symphodus melops, which accounted for $49.6 \%$, and that for C. melanocercus was $S$. tinca, which accounted for $23.0 \%$ of total interactions).

The differences reported above point out that although $D$. sargus shows high cleaning rates compared to other temperate cleaner species, it is a rudimentary opportunistic cleaner spending less time cleaning and interacting with a limited number of client species.

Regardless of this lack of specialization, there is a major difference in the abundances of these cleaner species in temperate coastal areas. Juveniles of the sparid $D$. sargus aggregate in large numbers in near- shore shallow and sheltered areas (García-Rubies \& Macpherson 1995, Vigliola et al. 1998, Dias et al. 2016), while the labrids $C$. exoletus and $C$. melanocercus occur in comparatively low numbers in subtidal cleaning stations (Arnal \& Morand 2001b, Zander \& Sötje 2002, Sabatino et al. 2007). The high densities of juvenile $D$. sargus, specially from spring to autumn (Dias et al. 2016), compared with the much lower numbers of solitary and territorial $C$. exoletus and $C$. melanocercus, highlight the potential importance of $D$. sargus cleaning behaviour in temperate communities. In fact, $D$. sargus cleaning behaviour adds to the relevance of this pivotal species used as a model for population interconnectivity studies (Abecasis et al. 2013), monitoring the effectiveness of marine protected areas (Lloret \& Planes 2003, Guidetti et al. 2008, Abecasis et al. 2015), or evaluating the impact of climatic changes including the potential effect of invasive species (Magliozzi et al. 2017). Fluctuations in the abundance of young $D$. sargus due to environmental changes or overfishing may have conse- 
Table 4. Comparison of the cleaning frequencies per target species for each temperate cleaner species: Diplodus sargus (this work), Centrolabrus exoletus (Henriques \& Almada 1997), and Centrolabrus melanocercus (Sabatino et al. 2007). The values for the 3 most important client species for each temperate cleaner species are displayed in bold

\begin{tabular}{|c|c|c|c|c|c|c|c|}
\hline \multirow[t]{3}{*}{ Host family } & \multirow[t]{3}{*}{ Host species } & \multicolumn{6}{|c|}{ Frequency of interactions $\left(\mathrm{h}^{-1}\right)$ and rank } \\
\hline & & \multicolumn{2}{|c|}{ D. sargus } & \multicolumn{2}{|c|}{ C. exoletus } & \multicolumn{2}{|c|}{ C. melanocercus } \\
\hline & & Freq. & Rank & Freq. & Rank & Freq. & Rank \\
\hline Mugilidae & Unidentified & 12.16 & 1 & 0.04 & 8 & & \\
\hline Apogonidae & Apogon imberbis & & & & & 0.03 & 18 \\
\hline \multirow[t]{8}{*}{ Sparidae } & Boops boops & 0.22 & 3 & & & & \\
\hline & Diplodus annularis & & & & & 0.16 & 7.5 \\
\hline & Diplodus puntazzo & & & & & 0.09 & 12 \\
\hline & Diplodus sargus & 0.20 & 4 & 0.04 & 8 & 0.16 & 7.5 \\
\hline & Diplodus vulgaris & & & 0.18 & 5 & 0.06 & 15 \\
\hline & Oblada melanura & 0.02 & 7 & & & 0.03 & 18 \\
\hline & Sarpa salpa & 0.28 & 2 & 0.06 & 6 & 0.66 & 3 \\
\hline & Spondyliosoma cantharus & & & 0.02 & 11 & & \\
\hline Pomacentridae & Chromis chromis & & & & & 0.06 & 15 \\
\hline \multirow[t]{11}{*}{ Labridae } & Coris julis & & & 0.30 & 3 & 0.47 & 4 \\
\hline & Ctenolabrus rupestris & & & 0.02 & 11 & & \\
\hline & Labrus bergylta & & & 1.64 & 2 & & \\
\hline & Labrus viridis & & & & & 0.13 & 9.5 \\
\hline & Symphodus cinereus & & & & & 0.09 & 12 \\
\hline & Symphodus mediterraneus & & & & & 0.13 & 9.5 \\
\hline & Symphodus melops & 0.02 & 7 & 2.52 & 1 & & \\
\hline & Symphodus ocellatus & & & & & 0.06 & 15 \\
\hline & Symphodus roissali & & & 0.20 & 4 & 0.19 & 6 \\
\hline & Symphodus rostratus & & & 0.04 & 8 & 0.09 & 12 \\
\hline & Symphodus tinca & & & & & 1.09 & 1 \\
\hline Moronidae & Dicentrarchus labrax & 0.04 & 6 & & & & \\
\hline Mullidae & Mullus surmuletus & & & & & 0.03 & 18 \\
\hline Carangidae & Seriola sp. & 0.06 & 5 & & & & \\
\hline \multirow[t]{2}{*}{ Serranidae } & Serranus cabrilla & & & & & 0.31 & 5 \\
\hline & Serranus scriba & & & & & 0.91 & 2 \\
\hline \multirow[t]{2}{*}{ Molidae } & Mola mola & & & 0.02 & 11 & & \\
\hline & TOTAL & 13.00 & & 5.08 & & 4.75 & \\
\hline
\end{tabular}

quences for the health of local fish communities and should be further investigated.

From a different perspective, efforts to develop a prospective aquaculture exploration of white seabream (Papandroulakis et al. 2004, Ozorio et al. 2006), limited by their aggressive behaviour towards conspecifics (Gonçalves et al. 2015), could now follow an alternative path. Instead of evaluating solely the potential of this species as a primary target for the aquaculture industry, the high ectoparasite cleaning rates reported here also suggest that juveniles from this species could improve the conditions of other species reared in captivity, namely mugilid species (see Tancioni et al. 2016).

This is the first study quantifying cleaning behaviour by a non-labrid species in the northeastern Atlantic and Mediterranean. However, additional studies are needed to fully understand the contribution of juvenile white seabream to the health of temperate coastal fish communities.
Acknowledgements. This study was funded by FCT, MARE/ ISPA-IU (UID/MAR/04292/2019) and CCMAR (UID/Multi/ 04326/2019). The authors thank Jessica La Marfa, David Sarmento, Cláudia Cruz, Pedro Coelho, Henrique Folhas, Ana Coelho, Ruxanda Lungu and Gonçalo Silva for their help during field work. We also thank the photographers for the fish pictures included in the figures, kindly provided by Nuno Vasco Rodrigues (Centrolabrus exoletus, Coris julis, Labroides dimidiatus and Thalassoma pavo), Emanuel Gonçalves (Elacatinus evelynae) and Manu San Félix (Centrolabrus melanocercus).

\section{LITERATURE CITED}

Abecasis D, Abecasis AR (2015) First report of cleaning behaviour in white sea bream (Diplodus sargus). Mar Freshwat Behav Physiol 48:71-75

Abecasis D, Bentes L, Coelho R, Correia C and others (2008) Ageing seabreams : A comparative study between scales and otoliths. Fish Res 89:37-48

Abecasis D, Bentes L, Lino PG, Santos MN, Erzini K (2013) Residency, movements and habitat use of adult white seabream (Diplodus sargus) between natural and artificial reefs. Estuar Coast Shelf Sci 118:80-85

Abecasis D, Horta e Costa B, Afonso P, Gonçalves EJ, Erzini 
K (2015) Early reserve effects linked to small home ranges of a commercial fish, Diplodus sargus, Sparidae. Mar Ecol Prog Ser 518:255-266

Alaş A, Öktener A (2017) Confirmed occurrence of Caligus mugilis Brian (Copepoda, Siphonostomatoida; Caligidae) with morphological characters in Turkish marine waters. Thalassas 33:133-137

Almada VC, Almada F, Henriques M, Santos RS, Brito A (2002) On the phylogenetic affinities of Centrolabrus trutta and Centrolabrus caeruleus (Perciforms: Labridae) to the genus Symphodus: molecular, meristic and behavioural evidence. Arquipel Life Mar Sci 19:85-92

Almada F, Carpi P, Carlos F, Francisco SM and others (2017) Identification of adult and juvenile Atherina presbyter Cuvier, 1829 in a marine coastal area adjacent to Tagus estuary (NE Atlantic): a molecular tool for an ecological question. J Appl Ichthyol 33:168-173

Arnal C, Côté IM (2000) Diet of broadstripe cleaning gobies on a Barbadian reef. J Fish Biol 57:1075-1082

* Arnal C, Morand S (2001a) Cleaning behaviour in the teleost, Symphodus melanocercus: females are more specialized that males. J Mar Biol Assoc UK 81:317-323

Arnal C, Morand S (2001b) Importance of ectoparasites and mucus in cleaning interactions in the Mediterranean cleaner wrasse Symphodus melanocercus. Mar Biol 138: 777-784

* Arnal C, Côté IM, Sasal P, Morand S (2000) Cleaner-client interactions on a Caribbean reef: influence of correlates of parasitism. Behav Ecol Sociobiol 47:353-358

Arnal C, Verneau O, Desdevises Y (2006) Phylogenetic relationships and evolution of cleaning behaviour in the family Labridae: importance of body colour pattern. J Evol Biol 19:755-763

Ayling AM, Grace RV (1971) Cleaning symbiosis among New Zealand fishes. N Z J Mar Freshw Res 5:205-218

Baliga VB, Law CJ (2016) Cleaners among wrasses: phylogenetics and evolutionary patterns of cleaning behavior within Labridae. Mol Phylogenet Evol 94:424-435

*Barbu L, Guinand C, Bergmüller R, Alvarez N, Bshary R (2011) Cleaning wrasse species vary with respect to dependency on the mutualism and behavioural adaptations in interactions. Anim Behav 82:1067-1074

* Bertoncini ÁA, Machado LF, Barreiros JP, Hostim-Silva M, Verani JR (2009) Cleaning activity among Labridae in the Azores: the rainbow wrasse Coris julis and the Azorean blue wrasse Centrolabrus caeruleus. J Mar Biol Assoc UK 89:859-861

Bshary R (2002) Biting cleaner fish use altruism to deceive image-scoring client reef fish. Proc Biol Sci 269:2087-2093

Bshary R (2003) The cleaner wrasse, Labroides dimidiatus, is a key organism for reef fish diversity at Ras Mohammed National Park, Egypt. J Anim Ecol 72:169-176

Bshary R, Grutter AS (2005) Punishment and partner switching cause cooperative behaviour in a cleaning mutualism. Biol Lett 1:396-399

Bshary R, Schäffer D (2002) Choosy reef fish select cleaner fish that provide high-quality service. Anim Behav 63:557-564

* Cheney KL, Côté IM (2001) Are Caribbean cleaning symbioses mutualistic? Costs and benefits of visiting cleaning stations to longfin damselfish. Anim Behav 62:927-933

* Cheney KL, Côté IM (2005) Mutualism or parasitism? The variable outcome of cleaning symbioses. Biol Lett 1:162-165

Côté IM, Soares MC (2011) Gobies as cleaners. In: Patzner RA, Van Tassell JL, Kovačić M, Kapoor BG (eds) The biology of gobies. Science Publishers, Enfield, NH, p 525-551
Wias MS, Roma J, Fonseca C, Pinto M, Cabral HN, Silva A, Vinagre C (2016) Intertidal pools as alternative nursery habitats for coastal fishes. Mar Biol Res 12:331-344

Estabrook GF, Almada VC, Almada FJ, Robalo JI (2002) Analysis of conditional contingency using ACTUS2 with examples from studies of animal behavior. Acta Ethol 4: 73-80

Figueiredo M, Morato T, Barreiros JP, Afonso P, Santos RS (2005) Feeding ecology of the white seabream, Diplodus sargus, and the ballan wrasse, Labrus bergylta, in the Azores. Fish Res 75:107-119

*Floeter SR, Vázquez DP, Grutter AS (2007) The macroecology of marine cleaning mutualisms. J Anim Ecol 76:105-111

Galeote MD, Otero JG (1998) Cleaning behaviour of rock cook, Centrolabrus exoletus (Labridae), in Tarifa (Gibraltar strait area). Cybium 22:57-68

*García-Rubies A, Macpherson E (1995) Substrate use and temporal pattern of recruitment in juvenile fishes of the Mediterranean littoral. Mar Biol 124:35-42

* Gonçalves AR, Silva MF, Vendrell CL, Almada VC (2015) Agonistic behaviour and shoal composition of juvenile Diplodus sargus : first field observations. Environ Biol Fishes 98:1015-1021

*Gordoa A, Molí B (1997) Age and growth of the sparids Diplodus vulgaris, $D$. sargus and $D$. annularis in adult populations and the differences in their juvenile growth patterns in the north-western Mediterranean Sea. Fish Res 33:123-129

Grutter AS (1995) Relationship between cleaning rates and ectoparasite loads in coral reef fishes. Mar Ecol Prog Ser 118:51-58

*Grutter AS (1996a) Experimental demonstration of no effect by the cleaner wrasse Labroides dimidiatus (Cuvier and Valenciennes) on the host fish Pomacentrus moluccensis (Bleeker). J Exp Mar Biol Ecol 196:285-298

* Grutter A (1996b) Parasite removal rates by the cleaner wrasse Labroides dimidiatus. Mar Ecol Prog Ser 130:61-70

*Grutter AS (1997) Spatiotemporal variation and feeding selectivity in the diet of the cleaner fish Labroides dimidiatus. Copeia 1997:346-355

Grutter AS (1999) Cleaner fish really do clean. Nature 398: 672-673

*Gutter AS, Bshary R (2003) Cleaner wrasse prefer client mucus: support for partner control mechanisms in cleaning interactions. Proc R Soc B 270:S242-S244

*Grutter AS, Lester RJG (2002) Cleaner fish Labroides dimidiatus reduce 'temporary' parasitic corallanid isopods on the coral reef fish Hemigymnus melapterus. Mar Ecol Prog Ser 234:247-255

*Guidetti P, Milazzo M, Bussotti S, Molinari A and others (2008) Italian marine reserve effectiveness: Does enforcement matter? Biol Conserv 141:699-709

* Hanel R, Westneat MW, Sturmbauer C (2002) Phylogenetic relationships, evolution of broodcare behavior, and geographic speciation in the wrasse tribe Labrini. J Mol Evol 55:776-789

*Henriques M, Almada VC (1997) Relative importance of cleaning behaviour in Centrolabrus exoletus and other wrasse at Arrábida, Portugal. J Mar Biol Assoc UK 77: 891-898

Hobson ES (1968) Comments on certain recent generalizations regarding cleaning symbiosis in fishes. Pac Sci 23:35-39

Johnson WS, Ruben P (1988) Cleaning behavior of Bodianus rufus, Thalassoma bifasciatum, Gobiosoma evelynae, and Periclimenes pedersoni along a depth gradient at 
Salt River Submarine Canyon, St. Croix. Environ Biol Fishes 23:225-232

Krajewski JP (2007) Cleaning by the occasional cleaner Diplodus argenteus (Perciformes: Sparidae) in south Brazil: why so few client species? J Mar Biol Assoc UK 87: 1013-1016

Leitão F, Santos MN, Monteiro CC (2007) Contribution of artificial reefs to the diet of the white sea bream (Diplodus sargus). ICES J Mar Sci 64:473-478

Limbaugh C (1961) Cleaning symbiosis. Sci Am 205:42-49

Lloret J, Planes S (2003) Condition, feeding and reproductive potential of white seabream Diplodus sargus as indicators of habitat quality and the effect of reserve protection in the northwestern Mediterranean. Mar Ecol Prog Ser 248:197-208

Magliozzi L, Almada F, Robalo J, Mollo E and others (2017) Cryptic effects of biological invasions: reduction of the aggressive behaviour of a native fish under the influence of an 'invasive' biomolecule. PLOS ONE 12: e0185620

Mariani S (2001) Cleaning behaviour in Diplodus spp.: chance or choice? A hint for future investigations. J Mar Biol Assoc UK 81:715-716

Moosleitner VH (1980) Putzerfische und -garnelen im Mittelmeer. Zool Anz 205:219-240

Narvaez P, Furtado M, Neto AI, Moniz I, Azevedo JMN, Soares MC (2015) Temperate facultative cleaner wrasses selectively remove ectoparasites from their client-fish in the Azores. Mar Ecol Prog Ser 540:217-226

Nunes J de ACC, Sampaio CLS, Barros F (2013) How wave exposure, group size and habitat complexity influence foraging and population densities in fishes of the genus Halichoeres (Perciformes : Labridae) on tropical rocky shores. Mar Biol 160:2383-2394

* Oates J, Manica A, Bshary R, Grutter AS (2012) Relationship between roving behaviour and the diet and client composition of the cleaner fish Labroides bicolor. J Fish Biol 81:210-219

Ozorio ROA, Valente LMP, Pousao-Ferreira P, Oliva-Teles A (2006) Growth performance and body composition of white seabream (Diplodus sargus) juveniles fed diets with different protein and lipid levels. Aquacult Res 37: 255-263

Papandroulakis N, Kentouri M, Maingot E, Divanach P (2004) Mesocosm: A reliable technology for larval rearing of Diplodus puntazzo and Diplodus sargus sargus. Aquacult Int 12:345-355

Pinto A, Oates J, Grutter AS, Bshary R (2011) Cleaner wrasses Labroides dimidiatus are more cooperative in the presence of an audience. Curr Biol 21:1140-1144

Potts GW (1973) Cleaning symbiosis among British fish with special reference to Crenilabrus melops (Labridae). J Mar Biol Assoc UK 53:1-10

Quimbayo JP, Dias MS, Schlickmann ORC, Mendes TC (2017) Fish cleaning interactions on a remote island in the Tropical Eastern Pacific. Mar Biodivers 47:603-608

R Development Core Team (2019) R: a language and environment for statistical computing. R Foundation for Statistical Computing, Vienna. www.r-project.org

Reay PJ, Cornell V (1988) Identification of grey mullet (Teleostei: Mugilidae) juveniles from British waters. J Fish Biol 32:95-99

Robalo J, Mirimin L (2018) Population genetics of wild wrasse of interest to the aquaculture sector. In: Treasurer J (ed)
Cleaner fish biology and aquaculture applications. $5 \mathrm{~m}$ Publishing, Sheffield, p 197-209

* Rosa R, Lopes AR, Pimentel M, Faleiro F and others (2014) Ocean cleaning stations under a changing climate: biological responses of tropical and temperate fish-cleaner shrimp to global warming. Glob Chang Biol 20: 3068-3079

Rosecchi E (1987) L'alimentation de Diplodus annularis, Diplodus sargus, Diplodus vulgaris et Sparus aurata (Pisces, Sparidae) dans le Golfe du Lion et les lagunes littorales. Rev Trav Inst Peches Marit 49:125-141

Sabatino D, Mori M, Tunesi L (2007) Interazioni simbiotiche tra il labride pulitore Symphodus melanocercus e i suoi ospitti nel Mar Ligure. Thalass Salentina 30:117-127

Sala E, Ballesteros E (1997) Partitioning of space and food resources by three fish of the genus Diplodus (Sparidae) in a Mediterranean rocky infralittoral ecosystem. Mar Ecol Prog Ser 152:273-283

* Sampaio CLS, Loiola M, Colman LP, Medeiros DV and others (2017) Cryptobenthic fish as clients of French angelfish Pomacanthus paru (Pomacanthidae) during cleaning behaviour. Mar Biodivers Rec 10:1-4

Sazima I, Sazima C, Francini-Filho RB, Moura RL (2000) Daily cleaning activity and diversity of clients of the barber goby, Elacatinus figaro, on rocky reefs in southeastern Brazil. Environ Biol Fishes 59:69-77

* Soares MC, Côté IM, Cardoso SC, Bshary R (2008) The cleaning goby mutualism: a system without punishment, partner switching or tactile stimulation. J Zool (Lond) 276:306-312

* Stummer LE, Weller JA, Johnson ML, Côté IM (2004) Size and stripes: how fish clients recognize cleaners. Anim Behav 68:145-150

* Tancioni L, Caprioli R, Dawood Al-Khafaji AH, Mancini L, Boglione C, Ciccotti E, Cataudella S (2016) Anthropogenic threats to fish of interest in aquaculture: Gonad intersex in a wild population of thinlip grey mullet Liza ramada (Risso, 1827) from a polluted estuary in central Italy. Aquacult Res 47:1670-1674

Treasurer J (ed) (2018) Cleaner fish biology and aquaculture applications. 5m Publishing, Sheffield

Van Tassell JL, Brito A, Bortone SA (1994) Cleaning behavior among marine fishes and invertebrates in the Canary Islands. Cybium 18:117-127

Vasco-Rodrigues N, Fontes J, Bertoncini AA (2017) Cleaning interactions of fishes at São Tomé Island, West Africa. Cah Biol Mar 58:347-352

*Vaughan DB, Grutter AS, Costello MJ, Hutson KS (2017) Cleaner fishes and shrimp diversity and a re-evaluation of cleaning symbioses. Fish Fish 18:698-716

* Vigliola L, Harmelin-Vivien ML, Biagi F, Galzin R and others (1998) Spatial and temporal patterns of settlement among sparid fishes of the genus Diplodus in the northwestern Mediterranean. Mar Ecol Prog Ser 168: 45-56

Weitzmann B, Mercader L (2012) First report of cleaning activity of Lepadogaster candolii (Gobiesocidae) in the Mediterranean Sea. Cybium 36:487-488

*Whiteman E, Côté IM (2002) Cleaning activity of two Caribbean cleaning gobies: intra- and interspecific comparisons. J Fish Biol 60:1443-1458

Zander CD, Sötje I (2002) Seasonal and geographical differences in cleaner fish activity in the Mediterranean Sea. Helgol Mar Res 55:232-241

Submitted: February 11, 2019; Accepted: August 16, 2019

Proofs received from author(s): October 18, 2019 